\title{
PENYULUHAN DAN PRAKTIK PENCEGAHAN DEMAM BERDARAH DENGAN BAHAN ALAMI PADA KARANG TARUNA DESA KETEGAN
}

\author{
Galuh Ratmana Hanum ${ }^{1)}$, Syahrul Ardiansyah ${ }^{2)}$ dan Puspita Handayani $^{3 \text { ) }}$ \\ ${ }^{1,2}$ Fakultas Ilmu Kesehatan, Universitas Muhammadiyah Sidoarjo \\ ${ }^{3}$ Fakultas Ekonomi dan Bisnis, Universitas Muhammadiyah Sidoarjo \\ Email: ${ }^{1}$ galuhratmanahanum@umsida.ac.id, ${ }^{2}$ syahrulardiansyah@umsida.ac.id, \\ 3.pipit_puspita@umsida.ac.id
}

\begin{abstract}
Abstrak
Demam Berdarah Dengue (DBD) adalah penyakit yang ditularkan melalui gigitan nyamuk Aedes aegypti. Secara umum, banyak orang menangani Demam Berdarah Dengue (DBD) dengan menyemprotkan bahan kimia untuk mengurangi efek yang ditimbulkan. Pengabdian masyarakat ini diperkenalkan obat penolak nyamuk berbahan dari daun sawo. Daun sapodilla (Manilkara zapota) adalah salah satu tanaman yang mengandung fungsinya sebagai larvacides alami karena mengandung komposisi kimia yaitu flavonoid, saponin, tanin, alkaloid, dan minyak atsiri. Tujuan dari kegiatan ini adalah untuk menjelaskan tentang Demam Berdarah Dengue (DBD) dan memberikan pelatihan pemberantasan sarang nyamuk (PSN) menggunakan solusi bahan-bahan alami yang berasal dari daun sawo. Hasil dari kegiatan ini adalah para remaja memahami tentang Demam Berdarah Dengue (DBD) dan dapat membuat solusi yang berasal dari daun sawo sebagai pemberantasan sarang nyamuk menggunakan bahan-bahan alami.
\end{abstract}

Kata kunci: Demam Berdarah Dengue, Aedes aegypti, daun Sapodilla.

\begin{abstract}
Dengue Hemorrhagic Fever (DHF) is a disease transmitted by bite of Aedes aegypti. In general, many people handle Dengue Hemorrhagic Fever (DHF) by spraying containing chemicals, to reduce the effects caused. In this community service introduces mosquitoe repellent drug which is the ingredients from sapodilla leaves. Sapodilla leaves (Manilkara zapota) is one of the plants that contains have function as natural larvacides because the contains of chemical composition is flavonoids, saponins, tannins, alkaloids, and essential oils. The purpose of the activity was to educate about Dengue Hemorrhagic Fever (DHF) and mosquito nest eradication training (PSN) using a solution of natural ingredients derived from sapodilla leaves. The results of this activity are youth clubs understand about Dengue Hemorrhagic Fever (DHF) and can make a solution derived from sapodilla leaves as eradication of mosquito nests using natural ingredients.
\end{abstract}

Keywords: Dengue Hemorrhagic Fever, Aedes aegypti, Sapodilla leaves.

\section{PENDAhUluAN}

Indonesia merupakan salah satu negara yang beriklim tropis sehingga strategis untuk perkembangan flora dan fauna, tak terkecuali nyamuk. Penyakit yang penyebarannya melalui nyamuk, salah satunya adalah penyakit Demam Berdarah Dengue (DBD). Penyakit DBD merupakan penyakit yang disebabkan oleh virus dengue yang ditularkan melalui gigitan nyamuk dari genus Aedes, terutama Aedes aegypti (Zulkoni, 2010).
Penyakit DBD merupakan salah satu penyakit yang jumlah penderitanya semakin meningkat dan penyebarannya semakin luas, penykait DBD dapat menular dan menyerang umumnya pada usia anak-anak dan orang dewasa (Widoyono, 2005).

Penyakit DBD menjadi ancaman terbesar bagi kesehatan penduduk Indonesia karena kondisi iklim di Indonesia yang mendukung bagi berkembang biaknya nyamuk Aedes aegypti. Data dari Kementrian Kesehatan pada tahun 2017 kematian 
penderita DBD tertinggi terjadi di Provinsi Jawa Timur yaitu sebanyak 105 kematian (Depkes RI, 2018)

Desa Ketegan terletak di Kecamatan Tanggulangin dan Kabupaten Sidoarjo. Pada desa ketegan belum adanya pengendalian nyamuk yang efektif, aman, terjangkau dan berasal dari bahan alami. Oleh karena itu dilaksanan kegiatan pengabdian masyarakat dengan tujuan penyuluhan tentang penyakit Demam Berdarah Dengue (DBD) dan pelatihan pemberantasan sarang nyamuk (PSN) menggunakan larutan bahan alami yang berasal dari daun sawo.

\section{KAJIAN LITERATUR DAN PENGEMBANGAN HIPOTESIS}

Demam Berdarah Dengue (DBD) adalah penyakit infeksi yang disebabkan oleh virus dengeu yang ditularkan oleh nyamuk Aedes Spp. Gejala DBD antara lain sakit atau nyeri yang terjadi pada ulu hati, pendarahan dihidung, mulut, gusi atau memar pada area kulit.

Metode pengendalian nyamuk Aedes aegypti antara lain dengan pengendalian lingkungan, biologis dan kimiawi. Pengendalian lingkungan bertujuan untuk membatasi nyamuk berkembang biak, metode pengendalian lingkungan dengan cara $3 \mathrm{M}$ yaitu menguras, menutup dan mengubur. Tahapannya menguras bak mandi dan tempat penampung air, menutup rapat tempat penampung air dan mengubur barang bekas yang dapat menampung air. (Soegeng, 2006)

Metode selanjutnya adalah pengendalian biologis dengan cara memanfaatkan hewan atau tumbuhan seperti memelihara ikan cupang. Metode ketiga pengendalian nyamuk Aedes aegypti dengan pengendalian secara kimiawi menaburkan bubuk abate, fogging atau pengasapan (Soegeng, 2006).

Dampak yang merugikan akibat menggunakan insektisida kimiawi yaitu berbahaya bagi lingkungan sehingga menyebabkan resistensi terhadap serangga, mengganggu kesehatan dan pencemaran lingkungan. Oleh karena itu mendorong untuk mencari alternatif pemecahannya dengan cara memanfaatkan bahan alami yang berasal dari tumbuhan.

Tumbuhan yang berfungsi sebagai larvasida alami mempunyai kandungan senyawa kimia golongan flavonoid, saponin, tanin, alkaloid, dan minyak atsiri. Salah satu tumbuhan dengan kandungan tersebut yaitu daun sawo (Manilkara zapota). Penggunaan daun sawo (Manilkara zapota) merupakan salah satu alternatif insektisida alami yang dapat digunakan dalam kehidupan seharihari, karena daun sawo merupakan bahan limbah memudahkan masyarakat untuk menggunakan daun sawo sebagai insektisida alami daripada insektisida sintetis. Manfaat lain daun sawo bisa sebagai obat alternatif pereda demam, pendarahan luka dan bisul (Juwita, 2013).

\section{METODE PELAKSANAAN}

Kegiatan di desa Ketegan kecamatan Tanggulangin kabupaten Sidoarjo diawali dengan melakukan observasi setelah itu pendataan warga yang terkena DBD dan warga yang memiliki pengetahuan kurang tentang penyakit DBD. Setelah itu hasil observasi sebagai data acuan untuk mengidentifikasi masalah kegiatan penyuluhan terhadap tingkat pengetahuan masyarakat dan praktik dalam pencegahan demam berdarah dengan bahan alami pada karang taruna desa Ketegan. Kegiatan yang dilakukan seperti penyuluhan kesehatan tentang BDB dan pelatihan pemberantasan sarang nyamuk (PSN) menggunakan larutan bahan alami yang berasal dari daun sawo.

\section{HASIL DAN PEMBAHASAN}

Kegiatan ini dilaksanakan di Desa Ketegan Kecamatan Tanggulangin Kabupaten Sidoarjo. Pada tahun 2018 di Desa Ketegan terdapat beberapa warga penderita DBD. Berlatar belakang kejadian tersebut sehingga program pengabdian ini dilaksanakan yang bertujuan kasus tentang penyakit DBD bisa dicegah dan dapat merubah perilaku dan pola hidup sehat masyarakat menjadi lebih baik.

Sasaran kegiatan program ini adalah karang taruna Desa Ketegan. Kegiatan ini 
diawali dengan observasi berkunjung ke rumah warga untuk mendata warga yang terkena DBD dan warga yang memiliki pengetahuan kurang tentang penyakit DBD serta pemeriksaan jentik. Kegiatan yang kedua adalah penyuluhan kesehatan tentang penyakit DBD dan dan praktik dalam pencegahan demam berdarah dengan bahan alami menggunakan daun sawo, kegiatan penyuluan ini bertujuan untuk memberikan pendidikan kesehatan kepada masyarakat. Penyuluhan kesehatan ini dipaparkan mengenai cara menaggulangi kasus DBD dengan melaksanakan program 3M Plus dan praktik pembuatan larutan daun sawo untuk mematikan jentik nyamuk. Kegiatan yang ketiga adalah pemberantasan sarang nyamuk (PSN) dengan menggunakan larutan bahan alami yang berasal dari daun sawo yang diawali dengan menguras bak-bak penampungan air kemudian mengisi air bak yang telah ditambahkan larutan daun sawo kemudian dilanjutkan dengan menutupnya dan menimbun bak-bak penampung air yang tidak digunakan. Kegiatan yang terakhir adalah evaluasi. Evaluasi kegiatan ini akan dipantau kondisi lokasi sasaran.

Hasil yang didapat pada kegiatan ini yaitu kegiatan penyuluhan dan pelatihan pemberantasan sarang nyamuk (PSN) menggunakan larutan bahan alami yang berasal dari daun sawo mendapat tanggapan positif dari karang taruna desa Ketegan, terbukti dengan pemahaman yang bertambah tentang penyakit demam berdarah dan cara pemberantasan nyamuk nyamuk Aedes aegypti.

\section{KESIMPULAN}

Kegiatan pengabdian pada masyarakat tentang penyuluhan dan praktik pencegahan demam berdarah dengan bahan alami pada karang taruna desa ketegan dapat dilaksanakan dengan baik, lancar dan karang taruna memahami tentang penyakit Demam Berdarah Dengue (DBD) dan dapat membuat larutan yang berasal dari daun sawo sebagai pemberantas sarang nyamuk dengan menggunakan bahan alami.

\section{REFERENSI}

Direktorat Jenderal Pengendalian Penyakit dan Penyehatan Lingkungan. 2018. Tatalaksana Demam Berdarah Dengue di Indonesia. Jakarta: Departemen Kesehatan Republik Indonesia.

Juwita J. 2013. Aktivitas antibakteri ekstrak buah muda, daun dan kulit batang sawo manila (Manilkara zapota (L.) Van Royen) terhadap Vibrio cholerae dan Clostridium perfringens. Fakultas Teknobiologi Universitas Atma Jaya Yogyakarta.

Soegeng, Soegijanto. 2006. Demam Berdarah Dengue. Surabaya: Airlangga University press.

Widoyono, 2005, Penyakit Tropis : Epidemiologi, Penularan, Pencegahan, dan Pemberantasannya, 1 : 14-15, Jakarta, Penerbit Erlangga.

Zulkoni Akhsin. 2010. Parasitologi. Yogyakarta: Nuha Medika 
